\title{
Pengaruh Model Project Based Learning Berbantuan Multimedia Terhadap Pemahaman Konsep Siswa Pada Materi Tekanan Zat Cair di SMPN 18 Palu
}

\author{
Julianti, Unggul Wahyono, dan Sahrul Saehana \\ Juliantijuli93@yahoo.com \\ Program Studi Pendidikan Fisika FKIP Universitas Tadulako \\ Jl. Soekarno Hatta Km. 9 Kampus Bumi Tadulako Tondo Palu - Sulawesi Tengah
}

\begin{abstract}
Penelitian ini bertujuan untuk mengetahui pengaruh model project based learning berbantuan multimedia terhadap pemahaman konsep siswa pada materi tekanan zat cair di SMPN 18 Palu. Metode yang digunakan adalah eksperimen kuasi dengan the non-equivalent pretest-posttest design. Populasi penelitian ini adalah seluruh siswa kelas VIII SMPN 18 Palu. Teknik pengambilan sampel adalah purposive sampling. Kelas VIII-A sebagai kelas kontrol dan kelas VIII-B sebagai kelas eksperimen. Instrumen pemahaman konsep berupa tes essai yang telah divalidasi oleh validator. Rata-rata pemahaman konsep yang mengikuti modell pembelajaran project based learning berbantuan multimedia adalah 54,34 yang berkriteria sedang dan rata-rata yang mengikuti model project based learning tanpa bantuan multimedia adalah 44,78 juga yang berkriteria sedang. Berdasarkan uji $\mathrm{N}$-Gain bahwa rata-rata pemahaman konsep siswa pada kelas eksperimen yang menggunakan model project based learning berbantuan multimedia lebih meningkat dibandingkan dengan kelas kontrol dengan model project based learning tanpa bantuan multimedia. Hasil perhitungan statistik dari pengujian hipotesis menggunakan uji-t didapatkan harga $t_{\text {hitung }}$ sebesar 2,31 dan $t_{\text {tabel }}$ pada taraf signifikansi 5\% dan $\mathrm{dk}=44$ adalah 1,68. Disimpulkan bahwa terdapat pengaruh model project based learning berbantuan multimedia terhadap pemahaman konsep fisika siswa pada materi tekanan zat cair di SMPN 18 Palu.
\end{abstract}

Kata Kunci: Project Based Learning, Multimedia, Pemahaman Konsep, Tekanan Zat Cair

\section{PENDAHULUAN}

Kurangnya pemanfaatan multimedia dan tidak adanya keterlibatan siswa pada proses pengamatan lansung dalam pembelajaran adalah salah satu faktor yang menyebabkan pemahaman konsep fisika siswa rendah.

Hakikat belajar sains tentu saja tidak cukup sekedar mengingat dan memahami konsep seperti yang ditemukan atau dilakukan oleh para ilmuwan. Akan tetapi, yang sangat penting adalah pembiasaan perilaku ilmuwan dalam menemukan konsep yang dilakukan melalui percobaan dan penelitian ilmiah. Proses penemuan konsep yang melibatkan keterampilan-keterampilan yang mendasar melalui percobaan ilmiah dapat dilaksanakan dan ditingkatkan melalui kegiatan laboratorium ${ }^{[1]}$.

Siswa dalam mengikuti proses pembelajaran sudah membawa konsep awal tentang fisika. Konsep awal itu mereka dapatkan dari pengalaman dan pengamatan mereka dalam kehidupan sehari-hari ${ }^{[2]}$. Rendahnya pemahaman konsep juga disebabkan karena dalam proses pembelajaran kurang mengajak siswa untuk belajar mengaplikasikan konsep fisika yang dipelajari dalam membuat suatu karya. Fisika telah mendasari perkembangan berbagai produk teknologi yang memudahkan kehidupan manusia. Namun hal ini jarang terkomunikasikan pada pembelajaran siswa di kelas yang mengaitkan antara konsep yang dipelajari dengan produk teknologi yang telah dikembangkan ${ }^{[3]}$.

Hal ini diperkuat dengan penelitian sebelumnya, yang menyatakan bahwa kebanyakan siswa tidak mampu menghubungkan apa yang mereka pelajari dengan bagaimana pengetahuan tersebut akan dipergunakan atau dimanfaatkan. Menurutnya siswa juga memiliki kesulitan untuk memahami konsep akademik karena mereka diajar menggunakan sesuatu yang abstrak dengan metode ceramah ${ }^{[4]}$. Untuk menjelaskan dan mengatasi hal tersebut diperlukan suatu media. Penggunaan media pembelajaran dengan basis teknologi memberikan dampak yang sangat positif bagi kemampuan dan kemauan siswa untuk mengikuti proses pembelajaran. Salah satu media pembelajaran yang dapat digunakan yaitu simulasi komputer sehingga siswa tidak 
hanya menghayal, tetapi siswa dapat melihat langsung konsep yang dijelaskan oleh guru ${ }^{[5]}$, sehingga peneliti disini menerapkan model project based learning berbantuan multimedia dalam proses pembelajaran.

Fokus dari Project Based Learning terletak pada konsep-konsep dan prinsip-prinsip inti dari suatu disiplin studi, melibatkan pebelajar dalam investigasi pemecahan masalah dan kegiatan tugas-tugas bermakna yang lain, memberi kesempatan pebelajar bekerja secara otonom untuk mengkonstruk pengetahuan mereka sendiri, dan mengkomunikasikannya dalam produk nyata. Project Based Learning merupakan sebuah pembelajaran inovatif yang menekankan belajar kontekstual melalui kegiatan-kegiatan yang kompleks. Adapun tahap-tahap pelaksanaan model project based learning adalah sebagai berikut: ${ }^{[6]}$

1. Penentuan Pertanyaan Mendasar (Start With the Essential Question).

2. Mendesain Perencanaan Proyek (Design a Plan for the Project)

3. Menyusun Jadwal (Create a Schedule)

4. Memonitor peserta didik dan kemajuan proyek (Monitor the Students and the Progress of the Project)

5. Menguji Hasil (Assess the Outcome)

Peneliti ini bertujuan untuk mengetahui pengaruh model pembelajaran project based learning berbantuan multimedia terhadap pemahaman konsep fisika siswa SMPN 18 Palu.

\section{METODE PENELITIAN}

Desain atau rancangan pada penelitian ini menggunakan "Non ekivalen pretest-posttest design" atau rancangan pretest-posttest yang tidak ekuivalen. Bentuk desainnya disajikan pada Tabel $1^{[7]}$.

Tabel 1. Desain Penelitian

\begin{tabular}{lccc}
\hline \multicolumn{1}{c}{ Kelompok } & Pre-tes & Perlakuan & Post-tes \\
\hline A (Eksperimen) & 0 & $X_{1}$ & 0 \\
B (Kontrol) & 0 & $X_{2}$ & 0 \\
\hline
\end{tabular}

Keterangan :

O : Tes awal (pretest) dan tes akhir (posttest)

$\mathrm{X}_{1}$ : Poject based learning berbantuan multimedia

$\mathrm{X}_{2}$ :Poject based learning tanpa bantuan multimedia

Populasi dalam penelitian ini adalah seluruh siswa kelas VIII SMPN 18 Palu. Dua kelas yang dijadikan tempat penelitian ini yaitu kelas eksperimen dengan model projct based learning berbantuan multimedia dan kelas kontrol menggunakan model project based learning tanpa multimedia.

Instrumen yang digunakan dalam penelitian ini yaitu dengan cara memberikan tes pemahaman konsep yang terkait dengan materi tekanan zat cair. Tes ini dibuat dalam bentuk essai. Proses analisis tes yaitu dengan validitas ahli yang ditekankan pada validitas isi dan validitas konstruksi.

\section{HASIL dan PEMBAHASAN}

Pretest (tes awal) digunakan untuk mengetahui kemampuan awal siswa sebelum mengikuti pembelajaran. Data pretest terdiri dari kelas eksperimen dan kelas kontrol yang masing-masing berjumlah 23 siswa. Skor maksimum pada tes adalah 100 . Skor rata-rata kelas eksperimen pada tes awal sebesar 30,89 dengan standar deviasi sebesar 11,94, sedangkan pada tes akhir memiliki skor ratarata sebesar 54,39 dengan standar deviasi 15,54 . Untuk kelas kontrol pada tes awal, skor rata-ratanya sebesar 27,59 dengan standar deviasi sebesar 9,00 dan pada tes akhir memiliki skor rata-rata sebesar 44,26 dengan standar deviasi 14,47. Adapun data hasil penelitian di atas, disajikan pada Tabel 2 :

Tabel 2. Nilai hasil tes pemahaman konsep pada tes awal dan tes akhir.

\begin{tabular}{lcccc}
\hline \multirow{2}{*}{ Uraian } & \multicolumn{2}{c}{ Kelas Kontrol } & \multicolumn{2}{c}{$\begin{array}{c}\text { Kelas } \\
\text { Eksperimen }\end{array}$} \\
\cline { 2 - 5 } & $\begin{array}{c}\text { Tes } \\
\text { awal }\end{array}$ & $\begin{array}{c}\text { Tes } \\
\text { akhir }\end{array}$ & $\begin{array}{c}\text { Tes } \\
\text { awal }\end{array}$ & $\begin{array}{c}\text { Tes } \\
\text { akhir }\end{array}$ \\
\hline Jumlah siswa & 23 & 23 & 23 & 23 \\
Nilai Minimum & 5 & 25 & 15 & 25 \\
Nilai Maksimum & 40 & 75 & 55 & 85 \\
Nilai Rata-rata & 27.59 & 44.62 & 30.89 & 54.39 \\
Simpangan Baku & 9.00 & 14.47 & 11.48 & 15.54 \\
\hline
\end{tabular}

Berdasarkan uji normalitas. Uji normalitas pada penelitian ini menggunakan uji Chikuadrat dengan kriteria penerimaan $\mathrm{X}^{2}$ Hitung $<$ $X^{2}$ tabel, taraf signifikansi $a=0,05$ dan derajat kebebasan $\mathrm{dk}=\mathrm{k}-3$. Berdasarkan hasil perhitungan pretest nilai $\chi^{2}$ hitung untuk kelas eksperimen adalah sebesar 4,48 dan untuk kelas kontrol sebesar 3,02 dengan $\chi_{\text {tabel }}^{2}$ sebesar 7,81. Sedangkan hasil perhitungan posttest nilai $\chi^{2}$ hitung untuk kelas eksperimen adalah sebesar 6,16 dan kelas kontrol sebesar 6,23 dengan $\chi_{\text {tabel }}^{2}$ sebesar 7,81 . 
Uji homogenitas pada penelitian ini menggunakan $u j i$ statistik $F$ dengan taraf signifikansi $a=0,05$ dan untuk pretest nilai varians kelas eksperimen sebesar 44,26 serta kelas kontrol sebesar 27,59. Berdasarkan hasil perhitungan, diperoleh nilai $F_{\text {hitung }}$ sebesar 1,76 sedangkan nilai $F_{\text {tabel }}$ sebesar 2,03. Sedangkan, untuk posttest nilai varians kelas eksperimen sebesar 54,39 serta kelas kontrol sebesar 44,03. Berdasarkan hasil perhitungan, diperoleh nilai $F_{\text {hitung }}$ sebesar 1,15 sedangkan nilai $F_{\text {tabell }}$ sebesar 2.03.

Setelah dilakukan uji normalitas dan homogenitas, maka dilanjutkan dengan uji beda rata-rata ( 1 pihak) atau uji t. dimana $\mathrm{H}_{1}$ diterima jika -jika $t_{\text {hitung }}>t_{\text {tabel }}$, diketahui data dari postest yaitu 2,31>1,68. Hal ini menunjukkan bahwa $t_{\text {hitung }}$ berada diluar daerah penerimaan Ho. Dengan demikian $\mathrm{H}_{1}$ diterima dan $\mathrm{H}_{0}$ ditolak. Artinya bahwa hasil belajar siswa yang mendapatkan pembelajaran project based learning berbantuan multimedia lebih signifikan daripada siswa yang mendapatkan pembelajaran project based learning tanpa bantuan multimedia.

Berikut adalah tampilan simulasi dan animasi yang digunakan dalam penelitian.

\section{1) Simulasi Tekanan Hidrostatis}

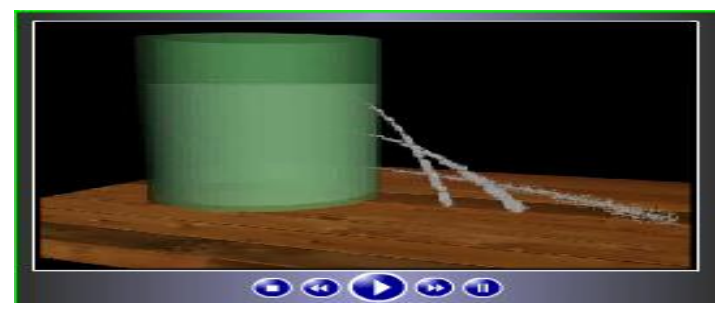

Gambar 1. Tampilan Simulasi Tekanan Hidrostatis

Gambar 1 menjelaskan tentang tekanan hidrostatis pada sebuah bejana yang berisi air. Simulasi ini menggambarkan tentang pengaruh tekanan terhadap kedalaman suatu zat cair. Dapat dilihat pada gambar di atas bahwa pancaran air yang keluar dari setiap lubang dari ketinggian yang berbeda menghasilkan pancaran air yang berbeda pula. Hal ini sesuai dengan persamaan matematis $\mathrm{P}=\rho \mathrm{gh}$, yang berarti bahwa tekanan hidrostatis bergantung pada ketinggin atau kedalaman zat cair. Gaya gravitasi menyebabkan zat cair dalam suatu wadah selalu tertarik ke bawah. Makin tinggi zat cair, semakin berat pula zat cair itu sehingga makin besar pula tekanan zat cair pada dasar wadah.

\section{2) Simulasi hukum Pascal}

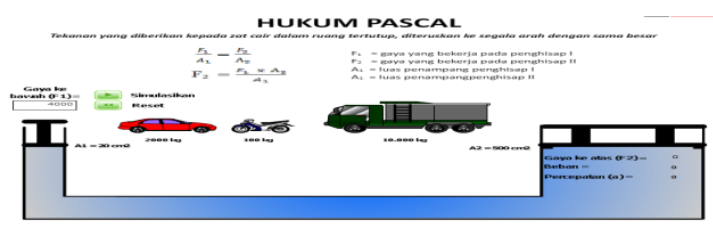

Gambar 2. Tampilan Simulasi Hukum Pascal

Gambar 2 menunjukkan tentang simulasi Hukum Pascal. Simulasi ini menggambarkan sistem kerja dongkrak hidrolik, terutama pada pencucian mobil yang sering dijumpai dalam kehidupan sehari-hari. Pada Gambar di atas terdapat beberapa komponen, dimana terdapat penampang, beberapa beban dengan massa yang berbeda beda. Pada Gambar di atas dongkrak hidrolik terdiri dari bejana dengan dua kaki yang masing-masing diberi pengisap. Pengisap 1 memiliki luas penampang $A 1$ dan pengisap 2 memiliki penampang $A 2$ yang bejananya diisi dengan cairan. Tersedia juga kotak untuk menginput nilai seberapa besar nilai gaya yang ingin kita gunakan dalam simulasi tersebut. Hukum Pascal menyatakan bahwa tekanan yang diberikan pada zat cair dalam ruang tertutup diteruskan sama besar ke segala arah, sehingga hanya dengan memberikan gaya yang kecil beban yang lebih besar bisa terangkat.

\section{3) Simulasi Hukum Archimedes}

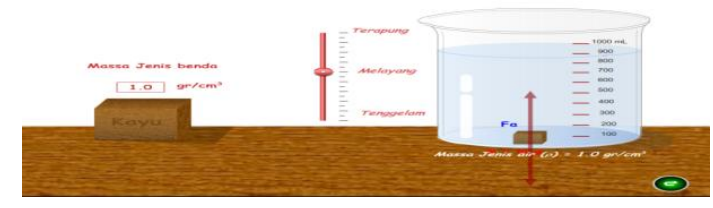

Gambar 3. Tampilan Simulasi Hukum Archimedes

Simulasi ini menjelaskan tentang pengaruh massa jenis terhadap peristiwa melayang, tenggelam dan terapungnya suatu benda. Pada Gambar simulasi Hukum Archimedes terdapat beberapa komponen yang tersedia, yaitu terdapat gelas yang berisi air, dan subuah benda yang akan dicelupkan ke dalam bejana yang berisi air. Pada gambar tersebut juga terdapat skala pengukur untuk membaca nilai berapa besar massa beban yang dicelupkan kedalam air, yang menyebabkan benda tersebut dalam keadaan tengelam, melayang, dan terapung. Benda dikatakan terapung apabila massa jenis benda lebih kecil dari massa jenis zat cair, benda dikatakan 
melayang apabila massa jenis benda sama dengan massa jenis zat cair, sedangkan dikatakan tenggelam apabila massa jenis benda lebih berat daripada massa jenis at cair.

\section{4) Animasi Hukum Pascal}

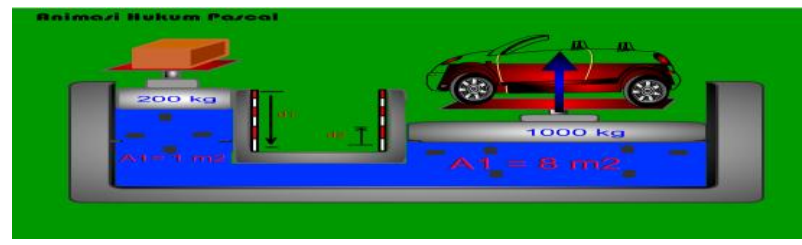

Gambar 4. Tampilan Animasi Hukum Pascal

Pada dasarnya sistem kerja animasi dan simulasi Hukum Pascal adalah sama namun pada sumulasi terdapat tombol kontrol sebagai pengendali dan kotak input nilai yang tersedia untuk memasukkan nilai seberapa besar nilai yang akan kita gunakan dalam simulasi tersebut, sedangkan pada animasi tidak tersedia kedua komponen tersebut. Pada gambar animasi di atas terlihat beberapa komponen yang tersedia yaitu, beban dengan massa yang berbeda, penampang yang berisi zat cair dengan pengisap 1 dengan luas $A 1$ dan pengisap 2 dengan luas $A 2$, sehingga tekanan yang dihasilkan pada penampang $A 1$ diteruskan Ke penampang A2 dengan sama besar. Sesuai dengan hukum pascal yang menyatakan bahwa tekanan yang diberikan pada zat cair dalam ruang tertutup diteruskan sama besar ke segala arah. Sehingga hanya dengan memberikan gaya yang kecil beban yang lebih besar bisa terangkat.

\section{5) Animasi tekanan hidrostatis}

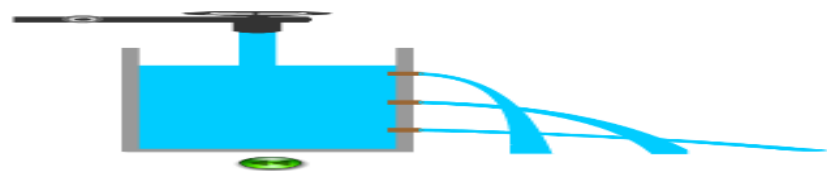

Gambar 5. Tampilan Animasi Tekanan Hidrostatis

Gambar 5 menjelaskan tentang animasi tekanan Hidrostatis. Pada Gambar 5 terlihat bahwa air mengalir dari keran ke sebuah wadah yang berlubang. Pada Gambar di atas terlihat beberapa lubang dengan ketinggian yang berbeda-beda yang menghasilkan jarak pancaran yang berbeda-beda pula. Hal ini sesuai dengan persamaan tekanan Hidrostatis, yang menyatakan bahwa tekanan bergantung pada ketinggian atau kedalaman zat cair. Semakin tinggi zat cair maka semakin besar tekanan zat cair pada dasar wadah. Sistem kerja pada animasi ini sama saja dengan sistem kerja pada simulasi tekanan hidrostatis. Hanya saja pada animasi tidak tersedia tombol kontrol pengatur animasi tersebut.

\section{6) Animasi Hukum Archimedes}

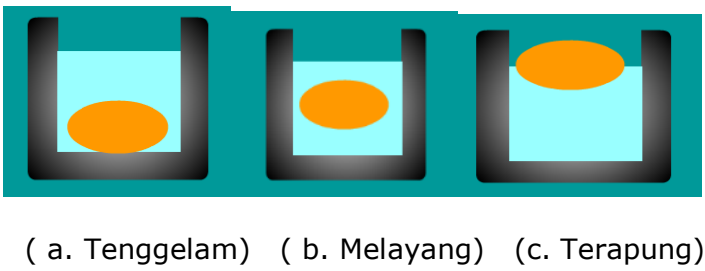

Gambar 6. Tampilan Animasi Hukum Archimedes

Pada Gambar animasi Hukum Archimedes terlihat beberapa komponen yang tersedia, yaitu sebuah bejana yang berisi air dan sebuah telur yang dimasukkan kedalamnya. Terlihat beberapa keadaan telur dalam wadah yaitu tenggelam, melayang dan terapung. Pada keadaan tenggelam massa jenis telur lebih besar dari massa jenis zat cair. Pada keadaan melayang yaitu massa jenis telur sama dengan massa jenis air, pada posisi ini air ditambahkan sedikit garam sehingga benda terangkat dengan posisi melayang. Pada keadaan terapung massa jenis telur lebih kecil daripada massa jenis air, pada keadaan ini air ditambahkan dengan banyak garam sehingga telur terangkat pada posisi terapung. Fungsi garam pada animasi ini yaitu untuk memperbesar massa jenis zat cair.

Diperolehnya hasil tersebut dimungkinkan karena dalam pembelajaran menggunakan model project based learning berbantuan multimedia, siswa berperan aktif dalam proses pembelajaran karena selain mereka memperagakan percobaan secara langsung mereka bisa juga melihat secara langsung konsep alat yang mereka peragakan melalui simulasi komputer sehingga guru hanya berperan sebagai fasilitator, para siswa juga dapat menguasai materi yang diajarkan dengan pemahaman konsep yang lebih kuat karena penjelasan cara kerja alat yang mereka peragakan akan ditampilkan kembali melalui gambar simulasi komputer yang dapat menarik perhatian dan menambah daya ingat mereka.

Hal ini sesuai dengan penelitian sebelumnya bahwa penggunaan multimedia interaktif yang dikaitkan dengan kehidupan nyata akan membuat pembelajaran lebih bermakna, dikarenakan peserta didik diajak menghubungkan konsep-konsep fisika yang 
dimilikinya untuk menjelaskan fenomenafenomena yang ada dalam kehidupan seharihari melalui bantuan multimedia interaktif yang dikaitkan dengan kehidupan nyata ${ }^{[8]}$.

Pada penelitian ini kelas eksperimen dan kelas kontrol diberi model pembelajaran yang sama yaitu model project based learning, seminggu sebelum pembelajaran kelompok siswa diberi LKS yang berisi penyajian masalah, langkah-langkah pembuatan alat sederhana yang akan dikerjakan secara berkelompok di rumah siswa. Kemudian pada saat pembelajaran berlangsung hasil rumusan masalah, hasil prediksi siswa dan langkahlangkah eksperimen didiskusikan sebelum melakukan eksplorasi. Oleh karena itu siswa telah memiliki pengetahuan awal tentang materi yang akan diajarkan dan dapat memudahkan siswa dalam menentukan konsep fisika yang terjadi pada saat melakukan percobaan.

Pada peneilitian ini diketahui bahwa walaupun diberi model pembelajaran yang sama, ada salah satu fase yang berbeda dari kelas eksperimen. Kelebihan dari model pembelajaran yang diterapkan pada kelas eksperimen yaitu menggunakan multimedia, sehingga ketika ditemukan kekeliruan melakukan praktikum maupun dalam membuat kesimpulan maka diperlihatkan simulasi untuk membantu memperbaiki kekeliruaan tersebut. Pengguanaan multimedia dalam kelas sangat membantu proses belajar mengajar, dapat membantu siswa memahami materi, aktif dan lebih tertarik dalam proses belajar.

Kelebihan dari model pembelajaran project based learning berbantuan multimedia adalah dapat meningkatkan keaktifan siswa. Melalui model pembelajaran ini siswa dilibatkan untuk aktif berfikir dan menemukan secara langsung pengertian atau konsep yang ingin diketahuinya. Selain dari kelebihan tersebatd,an adapula kekurangan dari model ini yaitu membutuhkan waktu yang cukup lama dalam bereksperimen untuk memperoleh kesimpulan atau suatu konsep yang utuh. Sehingga, dari hasil analisis skor rata-rata yang diperoleh masih dalam kriteria rendah, karena masih terdapat beberapa siswa yang melakukan aktivitas lain pada saat bereksperimen.

\section{KESIMPULAN}

Berdasarkan hasil penelitian dan analisis data, maka dapat disimpulkan bahwa rata-rata pemahaman konsep siswa pada materi tekanan zat cair antara kelas eksperimen dan kelas kontrol terdapat perbedaan yang signifikan. Berdasarkan uji N-Gain terlihat bahwa rata-rata pemahaman konsep siswa pada kelas eksperimen yang menggunakan model project based learning berbantuan multimedia lebih meningkat dibandingka dengan kelas kontrol dengan model project based learning tanpa bantuan multimedia. Dengan demikian dapat disimpulkan bahwa terdapat pengaruh pemahaman konsep pada siswa yang diberi model pembelajaran project based learning berbantuan multimedia dibandingkan dengan siswa menggunakan model project based learning tanpa bantuan multimedia.

\section{DAFTAR PUSTAKA}

[1]Rahmawati, D. (2011) "pengaruh model pembelajaran berbasis proyek terhadap hasil belajar siswa. "Jakarta : UINS yarif Hidayatullah

[2]Suparno, P. (2013). Miskonsepsi Dan Perubahan Konsep dalam Pendidikan Fisika. Jakarta : PT Gramedia Widiasarana Indonesia

[3]Wibowo, F.C. dkk (2013). "Penerapan Model Science Creative Learning (SCl) Fisika Berbasis Proyek Untuk Meningkatkan Hasil Belajar Kognitif Dan Keterampilan Berpikir Kreatif."Jurnal pendidikan IPA Indonesia. Vol.2, NO.1, tahun 2013. Tersedia dihttp://journal.unnes.ac.id/nju/index.php/jpii

[4]Mahanal, S. (2009). Pengaruh Pembelajaran Project Based Learning (Pjbl) Pada Materi Ekosistem Terhadap Sikap Dan Hasil Belajar Siswa SMAN 2 Malang. Universitas Negeri Malang

[5] Some, I.M. (2013)"Pengaruh Penggunaan Macromedia Flash Terhadap Minat Belajar SiswaPada Mata PelajaranFisika"Jurnal Pendidikan 2013.

[6] Kemendikbud.(2013). Strategi Pembelajaran Berbasis Proyek. Pelatihan Pendampingan Kurikulum 2013. Jakarta: Pusat Pengembangan Tenaga Kependidikan Kemendikbud.

[7] Sudjana.(2005). Metode Statistika. Bandung : Cv Tarsito

[8] Novitasari. (2015). Prosiding Simposium Nasional Inovasi dan Pembelajaran Sains 2015 (SNIPS 2015) 8 dan 9 juni 2015. Bandung Indonesia. 